\title{
Lanskap Konteks Sosial-Sosietal \\ dalam Pragmatik Berbasis Cybertexts Vaksinasi Covid-19 \\ (Socio-Social Context Landscape in Cybertexts-Based Pragmatics Covid-19 Vaccination)
}

\author{
R. Kunjana Rahardi ${ }^{\mathbf{a}, 1}$ \\ ${ }^{a}$ Universitas Sanata Dharma, Yogyakarta, Indonesia \\ ${ }^{1}$ kunjana@usd.ac.id; rahardi.kunjana@gmail.com
}

\section{Article info}

Article history:

Received: 20-01-2021

Revised : 13-04-2021

Accepted: 07-05-2021

Keywords: social-societal context cybertexts

cyberpragmatics context landscape

\section{A B S T R A C T}

This study aims to describe the types of social-social context landscapes in cybertexts-based pragmatics related to the Covid-19 vaccination discourse. The research data is in the form of speech excerpts that contain the identity of the social-social context landscape in cybertexts. The data collection method applied is the listening method with reading and note-taking techniques. Furthermore, the data are identified, classified, and typified to apply data analysis methods and techniques. The data analysis method applied was the extra lingual equivalent method. The validity of the data used expert validation and theoretical triangulation. This study resulted in findings in the form of six types of social-social context landscapes for Covid-19 vaccination, namely (1) confirming the meaning of the speech, (2) clarifying the meaning of the speech, (3) informing the purpose of the speech, (4) setting the background for the speech, (5) supporting the meaning of the speech. the meaning of the speech, and (6) clarify the meaning of the speech.

Penelitian ini bertujuan mendeskripsikan jenis-jenis lanskap konteks sosial-sosietal dalam pragmatik berbasis cybertexts terkait dengan wacana vaksinasi Covid-19. Data penelitian berupa cuplikan-cuplikan tuturan yang di dalamnya terkandung identitas lanskap konteks sosial-sosietal dalam cybertexts. Metode pengumpulan data yang diterapkan adalah metode simak dengan teknik baca dan teknik catat. Selanjutnya data diidentifikasi, diklasifikasi, dan ditipifikasi untuk dikenakan metode dan teknik analisis data. Metode analisis data yang diterapkan adalah metode padan ekstralingual. Keabsahan data menggunakan validasi pakar dan triangulasi teori. Penelitian ini menghasilkan temuan berupa enam jenis lanskap konteks sosial-sosietal vaksinasi Covid-19, yakni (1) menegaskan maksud tuturan, (2) mengklarifikasi maksud tuturan, (3) menginformasikan maksud tuturan, (4) melatarbelakangi maksud tuturan, (5) mendukung maksud tuturan, dan (6) memperjelas maksud tuturan.

Copyright $\odot 2021$ Institut Agama Islam Negeri Syekh Nurjati Cirebon. All rights reserved.

\section{PENDAHULUAN}

Peran yang sangat penting dan mendasar dari konteks dalam memaknai maksud tuturan sudah sangat lama diperbincangkan orang. Peran dan fungsi konteks dalam studi maksud tuturan juga sudah lama diteliti oleh para linguis, khususnya mereka yang berkecimpung pada dunia pragmatik (Rahardi, 2020b; 
Ifantidou, 2013). Konteks dalam studi bahasa di masa lalu memang dipahami dengan sangat berbeda dibandingkan dengan konteks yang dipahami pada studi bahasa di masa sekarang.

Di masa lampau teknologi belum tampak ditali-temalikan dalam studi bahasa, tetapi sekarang mau tidak mau teknologi harus diperantikan secara integratif dalam studi maksud pada bidang pragmatik. Konteks di masa lalu juga cenderung bergeser pada masa sekarang ini, baik dalam dimensi elemenelemennya maupun dari dimensi aspek-aspek dari elemen konteks itu (Rozakis, 2007). Hal tersebut terjadi karena teknologi informasi, teknologi digital, dan teknologi internet sekarang ini telah berintegrasi dalam bahasa (Hartanto, 2015).

Maka studi bahasa yang tidak menautkan dengan jenis-jenis teknologi yang disebutkan di atas itu sesungguhnya bisa dikatakan tidak menemukan apa-apa dan cenderung menjadi sia-sia belaka. Seiring dengan kenyataan itu, perspektif dalam melihat bahasa juga berbeda. Di masa lalu orang menerapkan perspektif monomodalitas dengan fokus pada entitas bahasanya saja, sedangkan sekarang perspektif itu ditinggalkan dan orang bergeser pada perspektif baru yang disebut dengan multimodalitas (Leeuwen, 2005; Kress, 1990). Dalam perpektif baru tersebut, bahasa dipandang hanya sebagai bagian saja dari hal-hal lain yang perlu diperhatikan dalam komunikasi.

Perlu dijelaskan pula bahwa teknologi sesungguhnya merupakan bagian pokok dari budaya. Maka jika dikatakan bahwa bahasa itu bertali-temali dengan masyarakat, dan masyarakat itu bertali-temali dengan budaya, dengan sendirinya bahasa juga harus diyakini bertali-temali dengan teknologi itu. Relasi-relasi yang terdapat di dalamnya cenderung bersifat interweaving bagaikan benang-benang tenun yang merajut kain-kain tenun yang menjadikan benang-benang itu tidak lagi dapat dipisahkan antara satu dengan lainnya (Goddard, 2009). Di satu sisi, libatan teknologi dalam studi bahasa itu menyiratkan kemajuan dan sekaligus mendorong kemajuan yang pesat sekali, tetapi di sisi yang lain juga menjadikan studi bahasa itu tidak lagi sesederhana yang dilakukan pada masa-masa lampau.

Studi bahasa, khususnya yang bertali-temali dengan maksud, menjadi tidak sederhana untuk dilakukan. Konteks sosial-sosietal yang pada masa lalu sekadar dimahami sebagai entitas yang bertali-temali dengan aspek-aspek sosial saja seperti jarak sosial dan status sosial, sekarang elemen-elemennya terpaksa berubah berikut dengan aspek-aspek yang ada pada setiap elemen konteks sosial dan konteks sosietal itu (Rahardi, 2020; Mey, 2004). Dengan perkataan lain, lanskap konteks sosial-sosietal itu menjadi bergeser di era teknologi informasi seperti yang terjadi sekarang ini.

Penelitian singkat ini bertujuan untuk menginvestigasi pergeseranpergeseran manifestasi konteks itu, baik dalam hal elemen konteksnya maupun aspek-aspek dari setiap elemen dalam kedua jenis konteks itu. Hal ini masih sangat jarang dilakukan karena sebagian orang masih memerantikan konteks dalam perspektif konvensional untuk memaknai tuturan-tuturan dalam media sosial yang semua berbasis siber teks itu (Orsini-Jones \& Lee, 2018; Haider, 2019). Jadi, jelas sekali studi yang demikian ini tidak banyak menghasilkan temuan yang tepat, temuan yang sesuai dengan yang dicita-citakan karena peranti analisisnya pasti juga tidak tepat.

Ibarat orang menebang kayu, di masa lalu selalu saja digunakan peranti kapak dari batu, yang kemudian bermetamorfose menjadi kapak besi, dan di masa lalu orang sudah merasa sangat cukup dengan peranti itu untuk menebang pohon, 
seberapa pun ukuran dari kayu itu. Akan tetapi sekarang, menebang kayu dengan peranti kapak yang demikian itu cenderung sudah dianggap sebagai suatu tindakan yang tidak efektif dan sama sekali tidak efisien. Dikatakan demikian karena dalam sehari, barangkali seseorang atau sekelompok orang tertentu sebagai penebang kayu hanya mampu merobohkan satu atau dua batang pohon besar.

Dengan digunakannya peranti lain yang lebih modern, katakan saja seperti gergaji bermesin, atau bahkan mungkin dengan peranti teknologi lain yang memerantikan robot untuk menebang dan memotong-motong kayu, pekerjaan menebang pohon yang jumlahnya mungkin sekali ratusan di dalam sebuah hutan, bisa dilakukan dalam hitungan jam saja. Studi bahasa sesungguhnya dapat diibaratkan serupa dengan hal tersebut. Dalam studi bahasa perubahan serupa juga terjadi seiring dengan perkembangan dan pergeseran teknologi itu.

Menememukan maksud yang semakin kompleks dan rumit karena bertalitemali dengan teknologi dengan segala kompleksitasnya, tidak mungkin bisa ditemukan jika hanya dilakukan dengan peranti analisis yang biasa-biasa saja (Georgiadis \& Collado, 2014). Rahardi dalam studinya telah berhasil menemukan bahwa konteks dalam studi pragmatik sesungguhnya dapat diperinci menjadi bermacam-macam. Terdapat empat jenis konteks yang ditemukan dalam studinya, yakni konteks sosial, sosietal, kultural, dan situasional. Keempat jenis konteks itu sekarang sudah bertali-tyemali dengan teknologi pula sehingga menghasilkan lanskap konteks yang berbeda dengan konteks-konteks yang sudah banyak diperikan sebelumnya (Rahardi, 2020a). Konteks-konteks yang sufah bertalitemali dengan teknologi itulah yang disebut sebagai konteks eksternal virtual.

Rahardi (2019) pernah menegaskan bahwa konteks sosial merupakan konteks kemasyarakatan yang berdimensi mendatar atau horizontal. Konteks ini berdimensi relasi kesejawatan yang berciri sejajar, misalnya saja, relasi antarpedagang, antarpetani, antarguru, antardosen, antarkaryawan, dan seterusnya. Dengan perkataan lain, di dalam relasi tersebut terdapat hubungan yang berciri solidaritas, tidak ada pembedaan status antara pihak yang satu dengan pihak lainnya. Sementara itu konteks sosietal berciri vertikal dan di dalamnya terdapat dimensi kekuasaan atau power. Jadi, ada salah satu pihak yang dipandang lebih kuat dan berkuasa, dan ada pihak lain yang dipandang lebih rendah dan lemah kuasanya (Hay, 2000).

Relasi yang demikian ini terjadi dalam relasi antara dosen dengan mahasiswa, antara atasan dengan bawahan, antara pasien dengan dokter, antara polisi dengan pengguna jalan di jalan raya, dan seterusnya. Dengan perkataan lain, terdapat relasi yang bersifat 'power', yakni ada pihak yang di bawah dan ada pihak yang membawahi. Di dalam setiap jenis konteks yang disebutkan di depan itu terdapat elemen-elemen konteks yang bermacam-macam, yang tentu saja dapat diperinci menjadi bagian yang lebih terperinci lagi yang disebut dengan aspekaspek elemen konteks (Hyland, 2003). Teori-teori yang disampaikan di atas dipandang sebagai kerangka acuan dalam penelitian ini. Selain itu, teori-teori tersebut juga diperantikan sebagai pisau analisis untuk memecahkan masalah pada penelitian ini.

Penelitian ini bertujuan untuk mendeskripsikan jenis-jenis lanskap konteks sosial-sosietal dalam pragmatik berbasis cybertexts terkait dengan wacana vaksinasi Covid-19. Penelitian ini memiliki manfaat dalam dua hal. Secara teoretis, hasil penelitian ini berkontribusi dalam pengembangan ilmu bahasa pragmatik, khususnya dalam perspektif cyberpragmatics (Rahardi, 2020; Yus, 
2011). Pragmatik jenis ini mendasarkan data dan sumber data serta objek penelitiannya pada cybertexts. Teks-teks dalam perspektif siber demikian ini belum dijadikan sumber kajian pada penelitian-penelitian pragmatik sebelumnya. Kedua, penelitian ini juga sangat bermanfaat dalam pengembangan pembelajaran dan penelitian pragmatik.

Pengajaran pragmatik yang semula terlampau berfokus pada sumber-sumber data dan objek data lama, sekarang harus berubah menginklusikan bahan-bahan dari cybertexs. Praksis penelitian bahasa ini juga mengalami pergeseran serupa, dari semula yang berfokus pada objek penelitian dan masalah penelitian konvensional, sekarang harus berubah menali-temalikan kajian itu dengan teknologi yang bermanifestasi pada cybertexts (Locher, 2013a). Penelitian dengan fokus demikian ini menjadi semakin urgen untuk dilakukan agar persoalanpersoalan maksud yang tidak terjawab dengan penelitian-penelitian bahasa perspektif lama, dapat terjawab dengan baik dengan perspektif baru.

\section{METODE}

Penelitian lanskap konteks sosial-sosietal ini berjenis deskriptif kualitatif. Sebagai penelitian kualitatif, di dalam penelitian bahasa ini tidak ditemukan hitung-hitungan dan komputasi-komputasi dengan metode tertentu. Selanjutnya perlu disampaikan bahwa objek penelitian ini adalah identitas lanskap konteks sosial-sosietal dalam siber teks (Richards \& Rodgers, 2010). Dengan demikian wujud data dalam penelitian ini berupa cuplikan-cuplikan tuturan yang di dalamnya terkandung identitas lanskap konteks sosial-sosietal dalam siber teks tersebut.

Secara lokasional, data penelitian ini ditemukan dari media sosial yang berhasil dijangkau di seputar waktu pelaksanaan penelitian ini, yakni pada bulan November-Desember 2020. Selanjutnya, sumber data substantif penelitian ini adalah teks-teks terkait dengan vaksinasi Covid-19 dalam media sosial yang di dalamnya terkandung objek penelitian dan data penelitian seperti yang disebutkan di depan itu.

Metode pengumpulan data yang diterapkan dalam penelitian ini adalah metode simak yang diterapkan dengan teknik baca dan teknik catat. Penyimakan yang dimaksud dalam penelitian ini dilakukan bukan dengan cara mendengarkan, melainkan dengan cara membaca teks-teks yang menjadi sumber data dan data penelitian termaksud dengan secara cermat dan seksama (Sudaryanto, 2015). Jadi, perlu dicatat bahwa menyimak tidak selalu berarti mendengarkan sesuatu yang dilisankan. Dalam penelitian linguistik, menyimak dapat dimaknai dengan mencermati teks-teks tertulis secara seksama.

Setelah data dikumpulkan dengan baik, selanjutya data tersebut diidentifikasi, diklasifikasi dan ditipifikasi untuk dikenakan metode dan teknik analisis data. Dengan demikian, data tersebut telah benar-benar diap untuk dikenai metode dan teknik analisis data. Metode analisis data yang diterapkan dalam penelitian ini adalah metode padan jenis ekstralingual. Metode ini juga sering disebut sebagai metode kontekstual karena analisis pragmatik sesungguhnya hanya dapat dilakukan dengan cara mendasarkan pada konteksnya, khususnya konteks eksternal baik yang berjati diri sebagai konteks eksternal konvensional maupun konteks eksternal virtual (Sudaryanto, 2016; Mahsun, 2007; Rahardi, 2020). 
Sebelum data dianalisis dengan menerapkan metode dan teknik analisis data seperti yang disampaikan di depan, langkah memvalidasi data dilakukan terlebih dahulu oleh peneliti. Validitas data penelitian ini diperoleh dengan cara mentriangulasikan data karena penelitian ini bersifat kualitatif. Triangulasi dilakukan dengan dua macam cara, yakni triangulasi teori dan triangulasi pakar. Triangulasi teori dilakukan dengan cara mengonfirmasikan data penelitian ini kepada teori-teori terkait. Selain triangulasi teori, data penelitian ini juga dikonsultaiskan kepada pakar yang relevan dengan bidang penelitian ini. Dengan demikian, data yang dianalisis dalam penelitian lanskap konteks sosial-sosietal ini benar-benar telah memenuhi dimensi validitas dan realibilitas. Selanjutnya, langkah analisis data dilakukan seperti yang telah dipaparkan di depan.

Hasil analisis dan intepretasi data selanjutnya disajikan secara informal, yakni dengan menggunakan narasi biasa, bukan dengan pemerantian simbolsimbol dan aksioma-aksioma yang berupa rumus-rumus tertentu seperti yang lazim ditemukan dalam bidang-bidang di luar sosial-humaniora.

\section{HASIL DAN PEMBAHASAN}

Dalam pelaksanaan penelitian lanskap konteks sosial-sosietal ini telah ditemukan enam jenis lanskap konteks sosial-sosietal terkait dengan wacana vaksinasi Covid-19. Keenam jenis lanskap konteks tersebut disampaikan berurutturut sebagai berikut: (1) lanskap konteks beridentitas sosial untuk menegaskan maksud tuturan, (2) lanskap konteks beridentitas sosial untuk mengklarifikasi maksud tuturan, (3) lanskap konteks beridentitas sosietal untuk menginformasikan maksud tuturan, (4) lanskap konteks beridentitas sosietal untuk melatarbelakangi maksud tuturan, (5) lanskap konteks beridentitas sosietal untuk mendukung maksud tuturan, (6) lanskap konteks beridentitas sosietal untuk memperjelas maksud tuturan. Temuan hasil penelitian lanskap konteks tersebut dapat dilihat pada Tabel 1.

Pada bagian berikut, setiap jenis lanskap konteks sosial-sosietal yang ditemukan dalam penelitian ini dijelaskan satu per satu. Pembahasan jenis-jenis lanskap konteks tersebut mencakup hal-hal berikut: (1) menegaskan maksud tuturan, (2) mengklarifikasi maksud tuturan, (3) menginformasikan maksud tuturan, (4) melatarbelakangi maksud tuturan, (5) mendukung maksud tuturan, dan (6) memperjelas maksud tuturan.

\section{Lanskap Konteks Sosial untuk Menegaskan Maksud Tuturan}

Konteks sosial berciri horizontal. Dikatakan berciri horizontal karena konteks sosial demikian itu menunjuk pada relasi yang sejajar. Relasi sosial yang sejajar itu mengimplikasikan hubungan yang bersifat sejawat (Rahardi, 2018; Locher, 2013b). Konteks sosial yang berdimensi horizontal demikian itu di dalam cuplikan tuturan berikut ini bermanfaat untuk menegaskan maksud tuturan. Adapun maksud tuturan yang ditegaskan tersebut terkait dengan informasi vaksinasi Covid-19. Ingar-bingar vaksinasi Covid-19 yang telah terjadi selama ini juga diperjelas dalam cuplikan tuturan dan konteks tuturan pada data A1. S berikut ini. Dengan demikian dapat ditegaskan bahwa konteks salah satunya berhakikat sebagai penegas maksud tuturan.

Konteks yang selama ini berhakikat sebagai pelatar belakang maksud, dengan data S1. S berikut ini diperluas lebih lanjut, yakni bahwa hakikat konteks bukan saja sebagai pelatar belakang maksud melainkan bias juga sebagai penegas maksud tuturan (Rahardi, 2015). Dengan perkataan lain pula, hakikat konteks 
sosial itu selain sebagai pelatar belakang maksud juga berhakikat sebagai penegas maksud tuturan. Cuplikan tuturan berikut ini dapat dicermati lebih lanjut untuk memperjelas hal ini.

Tabel 1. Manifestasi Lanskap Konteks Sosial-sosietal

\begin{tabular}{ll}
\hline Kode data & Wujud Konteks \\
\hline Data A1. S & $\begin{array}{l}\text { Data dirilis Kompas.com pada } 19 \text { November } 2020 \text { untuk } \\
\text { menegaskan bahwa masyarakat memahami informasi }\end{array}$ \\
& $\begin{array}{l}\text { terkait vaksinas Covid-19. Selain itu, pro-kontra } \\
\text { penerimaan vaksinasi Covid-29 juga diberi penegasan }\end{array}$ \\
& oleh konteks tuturan ini. \\
Data A2.S & Data pada gambar tersebut merupakan cuplikan berita \\
& yang dirilis Detik.news pada tanggal 20 Desember 2020. \\
& Dalam cuplikan berita tersebut diketahui bahwa \\
& masyarakat menyambut positif vaksin covid-19 gratis di \\
& Indonesia. Masyarakat juga menyampaikan bahwa tenaga \\
& kesehatan dan masyarakat kelas bawah yang berhak \\
& mendapat vaksinasi pertama.
\end{tabular}

Data A1.SS Data pada gambar tersebut merupakan cuplikan berita yang dirilis Liputan6.com pada tanggal 16 Desember 2020 Dalam cuplikan berita tersebut, Wiku (Jubir Satgas Penanganan Covid-19) menyampaikan bahwa vaksin akan digratiskan untuk mencapai herd immunity sehingga covid-19 dapat segera berakhir. Selain itu, Bambang Heriyanto (Jubir PT Bio Farma) juga menyampaikan bahwa mereka siap mendukung kebijakan pemerintah.

Data A2.SS Data pada gambar tersebut merupakan unggahan twitter Ernest Prakasa pada tanggal 11 Desember 2020. Dalam unggahan tersebut Ernest mengungkapkan rasa terima kasihnya kepada Presiden Joko Widodo yang telah menghadirkan vaksin di Indonesia dan berharap agar selalu ada pengadaan vaksin sehingga dapat segera didistribusikan.

Data A3. SS Data pada gambar tersebut merupakan unggahan instagram lawancovid19_id. Dalam unggahan tersebut admin instagram lawancovid19_id mengutip pernyataan Kepala BPOM, Penny K. Lukito yang menjelaskan bahwa penelitian tentang vaksin telah berjalan sesuai dengan protokol yang disetujui dan sejauh ini tidak ada reaksi yang berlebihan setelah seseorang disuntik vaksin.

Data A4. SS Data pada gambar tersebut merupakan unggahan akun facebook About Tangerang pada tanggal 13 Januari 2021. Dalam unggahan tersebut admin akun facebook About Tangerang mengutip pernyataan Kepala BPOM, Penny K. Lukito yang menjelaskan bahwa vaksin Sinovac telah diuji coba tahap ketiga di Bandung dan telah memenuhi standar Jenis Lanskap konteks

Lanskap Konteks Beridentitas Sosial untuk Menegaskan Maksud Tuturan

Lanskap Konteks Beridentitas Sosial untuk Mengklarifikasi Maksud Tuturan

Lanskap Konteks Beridentitas Sosietal untuk Menginformasikan Maksud Tuturan

Lanskap Konteks Beridentitas Sosietal untuk Melatarbelakangi Maksud Tuturan

Lanskap Konteks Beridentitas Sosietal untuk Mendukung Maksud Tuturan

Lanskap konteks beridentitas sosietal untuk memperjelas maksud tuturan 
Data A1. S

Terkait hal ini, maka diperlukan upaya penyampaian informasi tentang vaksin Covid-19 yang lebih akurat kepada masyarakat. "Survei ini menunjukkan mayoritas masyarakat Indonesia telah mendengar tentang vaksin Covid-19 dan bersedia menerimanya." Kata Sekretaris Jenderal Kementerian Kesehatan Oscar Primadi. Kendati demikian, dalam survei tersebut masih terdapat sebagian kecil masyarakat yang meragukan vaksin dan menolak menerima vaksin virus corona.

Sumber: $\quad$ https://www.google.com/amp/s/amp.kompas.com/sains/read/ 2020/11/19/180300723/survei-vaksin-covid-19-mayoritas-penduduk-

indonesia-bersedia-divaksinasi.

Konteks: Data dirilis Kompas.com pada 19 November 2020 untuk menegaskan bahwa masyarakat memahami informasi terkait vaksinasi Covid-19. Selain itu, pro-kontra penerimaan vaksinasi Covid-29 juga diberi penegasan oleh konteks tuturan ini.

\section{Lanskap Konteks Sosial untuk Mengklarifikasi Maksud Tuturan}

Di dalam tuturan A2. S berikut ini, maksud dan konteks sosial tuturan ini memiliki tujuan yang berbeda dengan yang disampaikan pada cuplikan data sebelumnya. Dalam cuplikan tuturan ini, konteks yang beridentitas sosial tersebut dimaksudkan untuk mengklarifikasi maksud tuturan. Temuan ini sekaligus meluruskan pandangan para pengkaji konteks yang selama ini ada dalam berbagai buku pragmatik bahwa konteks berfungsi sebagai pelatar belakang maksud (Leech, 2007; Carbaugh \& van Over, 2013). Ternyata dalam konteks yang bertalitemali dengan siber teks sekarang ini, identitas konteks dapat bergeser dan maknanya melebar, bukan sekadar sebagai entitas yang melatarbelakangi maksud tetapi juga fungsi yang lainnya (Wilson, 2003).

Dalam data Data A2. S berikut ini konteks sosial tersebut berperan sebai pengklarifikasi maksud. Adapun yang lebih diklarifikasi di dalam data dan konteks berikut ini adalah fakta bahwa masyarakat ternyata menyambut baik dan positif kehadiran vaksin Covid-19. Selain itu, juga informasi terkait pihak yang berhak diprioritaskan untuk menerima vaksin diklarifikasi melalui konteks dan tuturan pada cuplikan berikut ini.

Data A2. S

Masyarakat menyambut positif vaksin covid-19 gratis di Indonesia. Mereka menilai tenaga kesehatan dan masyarakat kelas bawah yang layak pertama kali dapat vaksin.

Sumber: https://news.detik.com/video/2012200004/pendapat-masyarakatsoal-vaksin-covid-19-gratis

Konteks: Data pada gambar tersebut merupakan cuplikan berita yang dirilis Detik.news pada tanggal 20 Desember 2020. Dalam cuplikan berita tersebut diketahui bahwa masyarakat menyambut positif vaksin covid-19 gratis di Indonesia. Masyarakat juga menyampaikan bahwa tenaga kesehatan dan masyarakat kelas bawah yang berhak mendapat vaksinasi pertama. 


\section{Lanskap Konteks Sosietal untuk Menginformasikan Maksud Tuturan}

Lanskap konteks beridentitas sosietal berbeda dengan konteks dalam lanskap sosial. Kalau lanskap konteks sosietal berdimensi horizontal, dalam konteks sosietal lanskap itu berdimensi vertikal. Dalam konteks pragmatik siber, konteks eksternal virtual yang berdimensi vertikal itu terdapat dalam relasi yang sifatnya tidak sejajar, berdimensi status sosial dan jenjang sosial. Pakar tertentu menyebutnya sebagai relasi yang berdimensi power (Hay, 2000; Tarr \& Warren, 2002). Jadi berbeda sekali dengan konteks sosial yang berdimensi solidaritas karena sifatnya yang sejajar itu.

Dalam kaitan dengan data A1. SS berikut ini, dimensi power tersebut kelihatan dari informasi tentang vaksin Covid-19 yang hendak diberikan secara gratis kepada masyarakat agar terdapat herd immunity. Kebijakan yang disampaikan pemerintah tersebut jelas sekali menunjukkan dimensi vertikal, bukan dari bawah ke atas melainkan dari atas ke bawah. Kebijakan yang bersifat 'power' demikian itu ditopang oleh dokuman dari pihak perusahaan yang ditunjukkan untuk mengurusi vaksin di Indonesia, yakni Bio Farma. Jadi jelas sekali maksud dari lanskap konteks ini adalah untuk menginformasikan maksud tuturan dari pemerintah kepad amasyarakat nelalui media massa. Data A1. SS berikut ini dapat dicermati lebih lanjut berkenaan dengan hal ini.

Data A1. SS

"Vaksin akan digratiskan untuk mencapai herd immunity dalam rangka percepatan penanganan Covid-19 agar pandemic Covid-19 segera usai." Kata Wiku kepada.... Tak hanya Wiku, PT Bio Farma selaku salah satu perusahaan penyedia vaksin covid-19 juga menegaskan siap memproduksi untuk masyarakat Indonesia.

Sumber: $\quad$ https://m.liputan6.com/news/read/4435197/satgas-covid-19vaksin-digratiskan-untuk-capai-herd-immunity

Konteks: Data pada gambar tersebut merupakan cuplikan berita yang dirilis Liputan6.com pada tanggal 16 Desember 2020 Dalam cuplikan berita tersebut, Wiku (Jubir Satgas Penanganan Covid-19) menyampaikan bahwa vaksin akan digratiskan untuk mencapai herd immunity sehingga covid-19 dapat segera berakhir. Selain itu, Bambang Heriyanto (Jubir PT Bio Farma) juga menyampaikan bahwa mereka siap mendukung kebijakan pemerintah.

\section{Lanskap Konteks Sosietal untuk Melatarbelakangi Maksud Tuturan}

Konteks sosietal juga dimungkinkan berdimensi vertikal yang berarah dari bawah ke atas alias down to top. Hubungan yang demikian lazimnya terjadi pada konteks pertuturan orang biasa kepada pihak yang berada di tataran atas, baik yang secara konvensional kelihat maupun yang hanya bisa diidentifikasi secara virtual. Dalam cuplikan data A2. SS berikut ini, lanskap konteks sosietal itu kelihatan dari tuturan yang disampaikan oleh seseorang terkait dengan rencana kedatangan vaksin dan sindirannya untuk menangguhkan vaksin bagi pihak-pihak yang selama ini menolaknya.

Konteks relasi yang bersifat vertikal dalam cuplikan tersebut berfungsi untuk melatarbelakangi maksud tuturan (Pranowo, 2020; Joseph, 2005). Jadi, sejalan dengan yang disampaikan oleh sejumlah pakar selama ini, bahwa konteks sesungguhnya dimaksudkan untuk melatarbelakangi maksud tuturan. Dalam 
tuturan berperspektif siber teks seperti yang disampaikan pada data A2. SS berikut ini, kejelasan identitas landskap konteks itu dapat dicermati lebih lanjut.

Data A2. SS

Pak@jokowi, terima kasih karena vaksin sudah hadir. Semoga semakin banyak \& bias segera didistribusikan. Mengingat jumlahnya sangat terbatas, saya usul orang-orang yang memiliki jejak digital bahwa mereka tidak percaya COVID-19 ya dijadikan prioritas terakhir saja.

Sumber: Unggahan akun twitter Ernest Prakasa

Konteks: Data pada gambar tersebut merupakan unggahan twitter Ernest Prakasa pada tanggal 11 Desember 2020. Dalam unggahan tersebut Ernest mengungkapkan rasa terima kasihnya kepada Presiden Joko Widodo yang telah menghadirkan vaksin di Indonesia dan berharap agar selalu ada pengadaan vaksin sehingga dapat segera didistribusikan.

\section{Lanskap Konteks Sosietal untuk Mendukung Maksud Tuturan}

Konteks sosietal yang berdimensi vertikal seperti disebutkan di bagian terdahulu juga dapat berfungsi untuk mendukung maksud tuturan. Jadi fungsi konteks itu bukan tentang maksud tuturan itu sendiri melainkan lingkungannya yang dapat mendukung dan memperkuat maksud tuturan. Maksud tuturan menjadi perhatian pokok dalam studi pragmatik, apa pun jenis pragmatiknya. Dalam pragmatik berperspektif siber, misalnya saja, maksud itu sangat ditentukan oleh maksud yang telah bertali-temali dengan teknologi hingga kebanyakan bermanifestasi pada media sosial dan media massa daring (Rahardi, 2020; Wharton, 2009).

Hal demikian tentu belum pernah dipikirkan para ahli pragmatik yang pada saat dilahirkannya pragmatik, teknologi belum berkembang pesat dan bebas seperti yang terjadi sekarang ini. Dalam kaitan dengan konteks sosietal, hubungan yang tidak bersifat sejajar tersebut sangat menentukan maksud tuturan seperti yang terdapat pada Data A3. SS berikut ini. Oleh karena itu, untuk lebih memahami identitas konteks sosial tersebut cuplikan tuturan pada data berikut ini dapat dipertimbangkan lebih lanjut.

Data A3. SS

Penelitian ini telah berjalan sesuai dengan protocol yang telah disetujui. Sejauh ini tidak ditemukan adanya reaksi yang berlebihan atau Serious Adverse Event, hanya reaksi ringan seperti umumnya pemberian imunisasi.

Sumber: Unggahan akun instagram lawancovid19_id

Konteks: Data pada gambar tersebut merupakan unggahan instagram lawancovid19_id. Dalam unggahan tersebut admin instagram lawancovid19_id mengutip pernyataan Kepala BPOM, Penny K. Lukito yang menjelaskan bahwa penelitian tentang vaksin telah berjalan sesuai dengan protokol yang disetujui dan sejauh ini tidak ada reaksi yang berlebihan setelah seseorang disuntik vaksin.

\section{Lanskap Konteks Sosietal untuk Memperjelas Maksud Tuturan}

Dalam cuplikan data A4. SS berikut ini, lanskap konteks sosietal tesebut berfungsi untuk memperjelas maksud tuturan. Maksud dari tuturan itu sendiri diemban oleh substansi tuturannya, sedangkan peran dari konteks sosietal itu sekadar sebagai pemerjela maksud yang disampaikan (Mey, 2002). Pemerjelas 
maksud tersebut adalah dinyatakannya bahwa vaksin Sinovac telah diujicobakan di Bandung dan telah dinyatakan memenuhi standar keamanan WHO. Tentu saja, informasi ini disampaikan oleh pihak yang memiliki otoritas, sehingga menjadi semakin jelas bahwa konteksnya bersifat tidak sejajar karena identitasnya vertical. Cuplikan tuturan pada Data A3. SS berikut ini dapat dipertimbangkan lebih lanjut untuk memperjelas hal ini.

Data A4. SS

Kepala Badan Pengawas Obat dan Makanan (BPOM) Penny K. Lukito mengatakan vaksin Sinovac yang telah diuji coba tahap ketiga di Bandung telah memenuhi standar keamanan yang dinyatakan WHO.

Hal itu disampaikan dalam konferensi pers pengumuman pemberian izin penggunaan darurat vaksin atau emergency us authorization (EUA) yang digelar Senin...

Sumber: Unggahan akun facebook About Tangerang

Konteks: Data pada gambar tersebut merupakan unggahan akun facebook About Tangerang pada tanggal 13 Januari 2021. Dalam unggahan tersebut admin akun facebook About Tangerang mengutip pernyataan Kepala BPOM, Penny K. Lukito yang menjelaskan bahwa vaksin Sinovac telah diuji coba tahap ketiga di Bandung dan telah memenuhi standar keamanan WHO.

\section{SIMPULAN}

Pelaksanaan penelitian ini telah menemukan enam jenis lanskap konteks sosial-sosietal vaksinasi Covid-19. Jenis-jenis lanskap konteks yang ditemukan dalam penelitian ini mencakup hal-hal berikut: (1) lanskap konteks beridentitas sosial untuk menegaskan maksud tuturan, (2) lanskap konteks beridentitas sosial untuk mengklarifikasi maksud tuturan, (3) lanskap konteks beridentitas sosietal untuk menginformasikan maksud tuturan, (4) lanskap konteks beridentitas sosietal untuk melatarbelakangi maksud tuturan, (5) lanskap konteks beridentitas sosietal untuk mendukung maksud tuturan, (6) lanskap konteks beridentitas sosietal untuk memperjelas maksud tuturan. Sekalipun begitu, penelitian lanskap konteks ini masih terbatas pada data yang diambil pada periode yang sangat pendek, sehingga belum mampu menggambarkan lanskap konteks sosial-sosietal itu secara utuh. Pada pelaksanaan penelitian yang lebih lengkap di masa mendatang, keterbatasan di atas akan diupayakan untuk disempurnakan oleh peneliti. Peneliti lain yang memiliki minat pada penelitian serupa juga diundang untuk melakukan hal yang sama, sehingga diskripsi lanskap konteks sosial-sosietal tersebut akan menjadi lebih sempurna.

\section{DAFTAR PUSTAKA}

Carbaugh, D., \& van Over, B. (2013). Interpersonal Pragmatics and Cultural discourse. Journal of Pragmatics, 43(14), 3565-3578. https://doi.org/10.1016/j.pragma.2013.09.013

Georgiadis, A., \& Collado, A. (2014). "Context Analysis" in Green RFID Systems, October. https://doi.org/10.1017/CBO9781139343459.002

Goddard, C. (2009). Not Taking Yourself Too Seriously in Australian English: 
Semantic Explications, Cultural Scripts, Corpus Evidence. Intercultural Pragmatics, 6(1), 29-53. https://doi.org/10.1515/IPRG.2009.002

Haider, I. (2019). "Assessing Interlanguage Pragmatics Through Interactive Email Communication" in Global Perspectives on Language Assessment. https://doi.org/10.4324/9780429437922-11

Hartanto, B. (2015). Analisis Unsur Kohesi dalam Wacana Bahasa SMS (Short Massage Service). Indonesian Language Education and Literature, 1(1), 90-106.

Hay, J. (2000). Functions of Humour in The Conversations of Men and Women. Journal of Pragmatics, 32(2000), 709-742. https://doi.org/10.1016/S03782166(99)00069-7

Hyland, K. (1998). Persuasion and Context: The Pragmatics of Academic Metadiscourse. Journal of Pragmatics, 30(1998), 437-455. https://doi.org/10.1016/s0378-2166(98)00009-5

Ifantidou, E. (2013). Pragmatic Competence and Explicit Instruction. Journal of Pragmatics, 59(A), 93-116. https://doi.org/10.1016/j.pragma.2012.12.008

Joseph, C. A. B. (2005). Language in Contact and Literatures in Conflict: Text, Context, and Pedagogy. World Englishes, 24(2), 131-143. https://doi.org/10.1111/j.1467-971X.2005.00398.x

Kress, G. (1990). Critical Discourse Analysis. Annual Review of Applied Linguistics, 11, 84-99. https://doi.org/10.1017/S0267190500001975

Leech, G. (2007). Politeness: Is There an East-West divide? In Journal of Politeness Research, 3(2), 167-206. https://doi.org/10.1515/PR.2007.009

Locher, M. A. (2013a). Cyberpragmatics: Internet-Mediated Communication in Context. Journal of Pragmatics, 47(1), 128-130. https://doi.org/10.1016/j.pragma.2012.12.002

Locher, M. A. (2013b). Cyberpragmatics: Internet-Mediated Communication in Context. Journal of Pragmatics. https://doi.org/10.1016/j.pragma.2012.12.002

Mahsun. (2007). Metode Penelitian Bahasa: Tahapan Strategi, Metode, dan Tekniknya (Edisi Revisi). Jakarta: Raja Grafindo Persada.

Mey, J. L. (2002). Symbolic Domination and Postcolonial Contestation: Resources and Conditions. In Journal of Pragmatics, 34(3), 285-330. https://doi.org/10.1016/S0378-2166(02)80003-0

Mey, J. L. (2004). Pragmatics: An Introduction. Blackwell: Oxford UK and USA Cambrige.

Orsini-Jones, M., \& Lee, F. (2018). Intercultural Communicative Competence for Global Citizenship: Identifying Cyberpragmatic rules of engagement in telecollaboration. Switzerland: Springer. https://doi.org/10.1057/978-1-13758103-7

Pranowo, P. (2020). Perspektif Masyarakat Jawa Terhadap Pemakaian Bahasa Nonverbal: Studi Kasus Etnopragmatik. Litera, 19(1), 52-71. https://doi.org/10.21831/ltr.v19i1.28873

Rahardi, R. K. (2020). Pragmatik: Konteks Ekstralinguistik dalam Perspektif Cyberpragmatics. Yogyakarta: Penerbit Amara Books.

Rahardi, R. K. (2020). Building Critical Awareness of Corona Virus-related News: Cyber-pragmatic Study of COVID-19 Hoaxes on Social Media. International Journal of Advanced Science and Technology, 29(6), 5398-5409. 
Rahardi, R. K. (2015). Menemukan Hakikat Konteks Pragmatik. Prosiding Seminar PRASASTI, 17-23. https://doi.org/10.20961/PRAS.V0I0.63.G47

Rahardi, R. K. (2020a). Ketriaditisan Konteks Pragmatik Tuturan Tidak Santun: Perspektif Kultur Spesifik. Ranah: Jurnal Kajian Bahasa, 9(1), 106-128. https://doi.org/10.26499/rnh.v9i1.2340

Rahardi, R. K. (2020b). Triadic Functions of Situational Context of Hate Speeches : a Cyberpragmatic Perspective. Metalingua.

Richards, J. C., \& Rodgers, T. (1982). Method: Design, and Procedure Approach. Tesol Quarterly, 16(2), 153-168.

Rozakis, M. (2007). The cultural context of emergencies: Seeking for a(n) holistic approach on disaster management. Disaster Prevention and Management, 16(2), 201-209. https://doi.org/10.1108/09653560710739522

Sudaryanto. (2015). Metode dan Aneka Teknik Analisis Bahasa: Pengantar Penelitian Wahana Kebudayaan secara Linguistis (1st ed.). Yogyakarta: Sanata Dharma University Press.

Sudaryanto. (2016). Metode dan Aneka Teknik Analisis Bahasa (1st ed.). Sanata Dharma University Press.

Tarr, M. J., \& Warren, W. H. (2002). Virtual Reality in Behavioural Neuroscience and Beyond. Nature Neuroscience, 5, 1089-1092. https://doi.org/10.1038/nn948

van Leeuwen, T. (2005). Introducing Social Semiotics (1st ed.). USA: Routledge.

Wharton, T. (2009). Pragmatics and Non-verbal Communication. Cambridge University Press.

Wilson, D. (2003). Relevance and Lexical Pragmatics. Italian Journal of Linguistics, 15(2), 273-291.

Yus, F. (2011). Cyberpragmatics, Internet-mediated Communication in Context (A. Fetzer (ed.); 1st ed.). Amsterdam: John Benjamin Publishing Company. 